\title{
Personal Well-Being and Family Interactions of Working Couples With Preschool Children: A Correlational Study ${ }^{1}$
}

\author{
Danila Secolim Coser $^{2}$ \\ Cláudia Maria Simões Martinez \\ Renata Christian de Oliveira Pamplin \\ Universidade Federal de São Carlos, São Carlos-SP, Brazil
}

\begin{abstract}
This study's objective was to verify potential relationships among personal well-being, parental practices, and interactions between parents and preschool children reported by working fathers and mothers $(n=120,60$ couples $)$ from a city in the interior of São Paulo, Brazil. Data were collected using the Questionnaire on family and professional lives. Three scales were selected for data analysis: well-being; interaction between parents and children; and family life. Statistical tests (One-Way ANOVA and Pearson's correlation coefficient) showed negative correlations between childrearing practices and health problems reported by parents. Positive correlations were also found between reported parental interactions and child-rearing practices. Parental practices and interactions between parents and children varied according to the number of children (one or two).
\end{abstract}

Keywords: family relationships, parent child relations, family health, dual careers

\section{Bem-Estar Pessoal e as Interações Familiares de Casais Trabalhadores com Filhos Pré-Escolares: Um Estudo Correlacional}

\begin{abstract}
Resumo: $\mathrm{O}$ estudo teve por objetivo verificar a existência de relação entre a avaliação do bem estar pessoal, práticas parentais e interações com filhos pré-escolares declaradas por pais e mães ( $n=120,60$ casais) trabalhadores de uma cidade do interior de São Paulo. Os dados foram coletados por meio do Questionário sobre vida familiar e profissional. Para a análise dos dados foram selecionadas três escalas do instrumento: bem-estar, interações entre pais e filhos e vida familiar. Por meio de testes estatísticos (One-Way ANOVA e Teste de Correlação de Pearson) foram observadas correlações negativas entre as práticas educativas adotadas e os problemas de saúde declarados pelos pais, além de correlações positivas entre as interações dos pais e as práticas educativas declaradas. Foi verificado ainda as práticas parentais declaradas e as interações entre pais e filhos variaram em função do número de filhos (um ou dois).
\end{abstract}

Palavras-chave: relações familiares, relações pais-criança, saúde da família, dupla carreira

\section{Bienestar Personal y las Interacciones Familiares de Parejas Trabajadores con Hijos Preescolares: Un Estudio de Correlación}

\begin{abstract}
Resumen: El estudio tuvo como objetivo verificar la existencia de relación entre la evaluación del bienestar personal, prácticas educativas de los padres y la interacción con sus hijos en edad preescolar, por padres y madres $(n=120 ; 60$ parejas) trabajadores de una ciudad del interior de Sao Paulo-Brasil. Los datos fueron colectados a través de un Cuestionario sobre el trabajo y la vida familiar. Para análisis de los datos se seleccionaron tres escalas: bienestar, interacciones entre padres e hijos y vida familiar. Por medio de pruebas estadísticas (One-Way ANOVA y correlación de Pearson) se encontraron correlaciones negativas entre las prácticas educativas adoptadas por los padres y los problemas de salud informados, y correlaciones positivas entre las interacciones de los padres y las prácticas educativas declaradas. También se verificó que las prácticas educativas de los padres y la interacción entre padres e hijos variaron según el número de niños (un o dos).
\end{abstract}

Palabras clave: relaciones familiares, relaciones padres-niños, salud de la familia, doble carrera

The family is considered the first mediator between people and culture and it is through family interactions that social transformations are consolidated, influencing future family relationships. Technological, social and economic transformations favor changes in the structure, organization,

\footnotetext{
${ }^{1}$ Paper derived from postdoctoral research of the second author under the advisory of Professor Zelia Maria Mendes Biasoli Alves, Faculdade de Filosofia, Ciências e Letras de Ribeirão Preto da Universidade de São Paulo, in 2007. Support: National Council for Scientific and Technological Development (CNPq).

2 Correspondence address:

Danila Secolim Coser. Rua Bahia, 240, Saúde. CEP 13800-510. MogiMirim-SP, Brazil. E-mail: danilacoser@yahoo.com.br.
}

and standards of families, while also changing expectations and roles played by family members, which is "characterized by a process of bidirectional influence among family members and the different environments that compose social systems" (Dessen \& Polonia, 2007, p. 22).

In this context, men and women are encouraged to adopt traditional models of sexuality and a rigid division of roles and functions within the family according to sex (men as breadwinners and women as caregivers). At the same time, they are forced to adapt to social transformations, such as the requirements of the job market, valorization of individual growth, financial independence, and flexibility in the exercise 
of gender roles (Perlin \& Diniz, 2005). Such challenges in managing family and professional roles are especially true for families in which both the man and the woman in the couple have a professional occupation, and for women with greater frequency and intensity (Fontaine, 2007).

The theoretical framework adopted in this study is based on the theory of Ecological Systems, which focuses on the study of human development taking into consideration the individuals' aspects and those of the process, time and context (Cecconello \& Koller, 2003). In this study, the focus is on the aspects of development linked to the family context.

Family organization has gone through drastic changes over time due to economic, social and cultural changes. In Brazil, from the 1970s on, with the feminist revolution and industrial progress, the number of women with paid jobs increased steadily, consequently increasing the challenges families face in managing family and professional roles. Therefore, it is essential to study the family and the demands posed by professional life.

Considering such changes, families have shown different ways to reconcile the demands of professional roles and those of raising children. Many studies address child development based on the family relationships established when children are in their preschool period (Martinez, 1998; Martinez, Pamplin, \& Fontaine, 2009; Matias, Andrade, Fontaine, Alves, \& Martinez, 2008; Wagner, Predebon, Mosmann, \& Verza, 2005).

Usually, the family is indicated as being responsible for a child's developmental impairments due to factors such as: separation or marital difficulties; deficit in affective relationships; parental psychopathologies; alcoholism; lack of stimuli in academic activities; lack of the parental participation in school issues; lack of or low paternal participation (the father's direct interaction and participation in care provided to children); death of parents and/or their prolonged absences; domestic violence; competitive relationships; siblings rivalry; and other factors. (Ferreira \& Marturano, 2002; Marçal \& Silva, 2006; Masten, 2001; Masten, Best, \& Garmezy, 1990; Pianta \& Walsh, 1996; Santos \& Marturano, 1999; Williams \& Aiello, 2004; Gomes, Crepaldi, \& Brigas, 2013). These are considered risk factors for child development.

Risk factors can be defined as random negative events that increase the chances of an individual presenting physical, social or emotional problems over the course of life (Yunes \& Szymanski, 2001); that is, risk factors are those factors that favor the emergence of negative developmental results and which are present in the family, school and in the community. Risks may have a biological, psychological or social nature, and may exist within the individual or in the environment, or in the interaction between the two (Yunes \& Szymanski, 2001).

The influence of risk variables is associated with changes in parental practices and, consequently, in the involvement of parents with children and in their development (Alvarenga
\& Piccinini, 2001; Salvo, Silvares, \& Toni, 2005; Santos \& Marturano, 1999; Bolsoni-Silva \& Marturano, 2007, 2008; Bolsoni-Silva \& Loureiro, 2011).

Parental child-rearing practices refer to the strategies used by parents to achieve specific objectives in different domains (academic, social and affective) under certain circumstances and contexts. These strategies are designed to suppress inappropriate behavior or encourage appropriate behavior (Weber, Prado, Viezzer, \& Brandenburg, 2004). Paying appropriate attention, providing explanations and using rewards are examples of positive parental childrearing practices, while lack of affection, non-enforcement of parental rules, and inconsistent punishment are examples of negative parental child-rearing practices (Gomide, 2006).

It is worth noting that, according to Weber et al. (2004), in contrast with child-rearing practices, parental styles refer to the global pattern of characteristics of interaction between parents and children. Hence, parental styles refer to the set of parents' attitudes that creates an emotional climate in which the parents' behavior is expressed, including parental practices and other aspects concerning the interaction between parents and children with an established objective, such as: tone of voice; body language; mood swings, among others.

An appropriate family environment and positive parental practices reduce or counterbalance the unfavorable effects of risk factors. Bolsoni-Silva and Marturano (2002), surveyed various studies on parental practices and behavioral problems in light of social abilities theory and indicate the parental skills that collaborate with children's learning and socialization: dialoguing with children (expressing their own feelings and acknowledging their children's manifestations of feelings); avoiding the use of punishment and giving priority to the use of rewards when appropriate behavior is presented; ignoring inappropriate behavior; keeping promises (when parents make promises and do not keep them, children feel cheated, which harms the family's relationships and serves as an example indicating there is no need to fulfill one's word); negotiating and establishing rules for children according to their age and skills; and participation of both parents in sharing parenting responsibilities.

Based on the ecological perspective of human development (Bronfenbrenner, 1979/1996), Martinez (1998) highlights the importance of considering the interconnections among non-immediate systems, promoting the hypothesis that development is deeply affected by environments in which the person is not present but in which facts that affects events in the immediate environment occur. Bronfenbrenner (1979/1996), for example, describes the influences of the parents' professional environments on family dynamics, explaining that events taking place in the workplace can impact child development. In this context, the conditions of family life and personal well-being the parents experience 
can directly influence the family and either positively or negatively impact child development.

A study by Gomes, Crepaldi and Brigas (2013) reports that fathers with heavy workloads tend to become less involved with children, showing that the fathers' occupations interfere in their direct interaction with the family and consequently interferes in the development of children.

According to Menegatti (2002), depressive parents are less affectionate, less responsive and more irritable, hostile and critical, and also show less interest in their children's academic life when compared to those who do not report such psychological conditions (Coser, 2009). According to the review by Mendes, Loureiro, and Crippa (2008), maternal depression is associated with behavioral problems in children, in addition to depressive symptoms, and cognitive and social impairments. Thus, maternal depression is a risk factor for child development.

Ferriolli, Marturano and Puntel (2007) analyzed the association among variables in the family context and the risk for the development of emotional and behavioral problems in children. A total of 100 children between the ages of six and 12 and their respective families participated in the study. Variables from the family context, such as socioeconomic level, adverse events, maternal stress, and organization and structure of the family context, were assessed. Maternal stress was associated with mental health problems and is a risk factor for anxiety and depression among children. In this same line of investigation, Gomide, Salvo, Pinheiro and Sabbag (2005) report that stressed parents more frequently use negative childrearing practices, such as inconsistent punishment, neglect, negative monitoring and physical abuse.

If for working fathers occupation has been indicated as an important indicator of stress in the family environment (Coley, 2001), in the case of families in which both parents work outside the home, the impact of their professional lives on family life seems to be even greater. A study by Zanfelici (2009) on stress and burnout (the most extreme level of occupational stress) with working mothers of preschool children, reveals that women who reported more hours dedicated to domestic tasks reached the highest levels of stress and burnout and deemed themselves to be less involved with their children. Additionally, on days of heavy workload, the respondents reported they interacted less with their children in activities related to positive parental involvement like playing and talking. Again, parental involvement is shown to be affected by the responsibilities and relationships parents maintain in different spheres of their lives. Such responsibilities and relationships can either strengthen or weaken the parent-child relationship, according to Bronfenbrenner's Bioecological Model (Bronfenbrenner \& Ceci, 1994).

Fiorin, Patias and Dias (2011) reviewed the role of the contemporary woman and mother and concluded that women are in psychological distress due to concerned over their individual and professional development; at the same time personal fulfillment is achieved with motherhood and the successful upbringing of children.

The number of children seems to be directly related to practices and interactions adopted by the family. According to Piccinini, Pereira, Marin, Lopes and Tudge (2007), many changes are observed after the birth of a second child in the roles of each family member, in support networks (need to seek the support of grandparents or institutions such as daycare and schools), in the marital relationship (priority is given to the role of parents at the expense of the couple), in the first child's behavior (behavioral and physical responses - health problems, aggressiveness, setbacks in learning, sleeping issues, increased introversion - to obtain attention and recover interaction that is lost with the arrival of a new member in the family) and in the parents' relationship with the firstborn (less time to interact and poorer quality of interaction between parents and the child).

Considering the influences of the parents' personal lives in family interactions and, consequently, in the development of children, we believe it is important to study these variables and their respective correlations. Therefore, this study's objective was to verify potential correlations between personal well-being (health problems), parental practices and interactions of parents with preschool children, reported by working fathers and mothers, and the potential differences in the studied variables between families with one and two children.

\section{Method}

\section{Participants}

A total of 60 couples (120 individuals) from a city with 200,000 inhabitants in the interior of São Paulo, Brazil participated in this study. The average age of the women was 33 years old and men were aged 36 years old on average. Inclusion criteria were: (1) Husband and wife should work outside home for at least 15 hours per week; (2) Both should live together (same household); (3) They should have at least one child up to six years old; (4) The oldest child should not be older than 12 years of age; (5) Husband and wife should agree to answer the questionnaire separately and sign free and informed consent forms.

Based on demographic data collected in 2007, the characterization of the sample was performed in terms of number of children, monthly income, field of work, and schooling (Table 1).

In general, families had one or two children; most (35.9\%) reported a monthly income between $\mathrm{R} \$ 1,500$ and $\mathrm{R} \$ 3,000$; and most were government employees $(53.8 \%$ of women and $64.6 \%$ of men). Women more frequently reported postgraduate studies $(29.7 \%)$ while men more frequently reported high school (36.5\%). 
Table 1

Characterization of the Sample in Regard to the Number of Children, Monthly Income, Occupational Field, Education and Age

\begin{tabular}{|c|c|}
\hline \multicolumn{2}{|c|}{ Sample characterization } \\
\hline & $\%$ \\
\hline \multicolumn{2}{|l|}{ Number of children } \\
\hline 1 child & 54.7 \\
\hline 2 children & 41.4 \\
\hline 3 to 5 children & 3.9 \\
\hline \multicolumn{2}{|l|}{ Monthly income } \\
\hline$>\mathrm{R} \$ 1,500^{*}$ & 33.3 \\
\hline $\mathrm{R} \$ 1,500$ to $\mathrm{R} \$ 3,000$ & 35.9 \\
\hline $\mathrm{R} \$ 3,000$ to $\mathrm{R} \$ 4,500$ & 17.5 \\
\hline $\mathrm{R} \$ 4,500$ to $\mathrm{R} \$ 6,000$ & 7.5 \\
\hline $\mathrm{R} \$ 6,000$ to $<\mathrm{R} \$ 12,000$ & 5.8 \\
\hline \multicolumn{2}{|l|}{ Occupational field } \\
\hline Public sector & 40.8 \\
\hline Private sector & 51.2 \\
\hline \multicolumn{2}{|l|}{ Education } \\
\hline Primary and Middle School & 4.2 \\
\hline High School & 30.8 \\
\hline Bachelor's degree & 23.3 \\
\hline Specializing programs & 17.5 \\
\hline Graduate Studies & 24.2 \\
\hline
\end{tabular}

\section{Instruments}

Questionnaire on family and professional lives (EU-Project, 2003). This version was adapted by researchers from the Faculdade de Psicologia e de Ciências da Educação, Universidade do Porto. The female and male versions of this questionnaire are each composed of 314 items, which address various aspects of the couple's routine related to the reconciliation of family and professional demands. The questionnaire is divided into six general themes, which in turn are subdivided into specific topics, namely: (1) Occupation, which includes information concerning working hours and professional fulfillment, professional and family organization, reciprocal influence of professional and family lives, division of tasks, assessment of distribution of work, and desired division of family tasks; (2) Family life, which is subdivided into relationships between parents and children, perception of the needs and characterization of the behavior of children between 1 and 5 years old, relationships with the remaining children, and support network available; (3) Reconciliation, which addresses the respondents' strategies to reconcile professional and family lives, the couple's cohabitation, family and society rules; (4) Personal life, which is subdivided into items of life conception, the respondent's personal characteristics, social support, and personal well-being; (5) Cohabitation, which addresses information concerning the couple's relationship and its decision-making processes; (6) Socio-demographic data, which address information such as gender, age, education, income, etc.
To meet this study's objectives, data concerning Family and Personal Lives were selected from the following scales of the Questionnaire on family and professional lives (EU-Project, 2003):

Behavior of parents toward children scale (parental practices). Composed of six questions addressing parental behavior when dealing with problems with children. Scores range from 0 to 5 where the participants choose between two extreme potential responses in the face of a problem presented in the question (Cronbach's $\alpha=.768$ ).

Scale of interactions between parents and children. Composed of seven items addressing the activities and behaviors of parents in their interaction with their child. Scores range from 0 'never' to 5 'many times' (Cronbach's alpha $\alpha=$.789).

Well-being scale (health problems). Composed of 10 items addressing health problems experienced in the last six months. Scores range from 0 'never' to 5 'many times' (Cronbach's $\alpha=.809$ ).

\section{Procedure}

Data collection. Participants were identified through meetings with those responsible for higher education institutions, industries, primary education schools and health services in both the public and private sectors. The study's objectives and inclusion criteria were presented in these meetings to the potential participants working in these institutions. After the participants were selected, the questionnaire was distributed with a brief explanation: this is a study with the objective to understand how working fathers and mothers of small children reconcile demands of family life with those from their occupation. Husbands and wives were instructed to answer the questionnaire separately. At this time, they were also given an overview of parts of the questionnaires concerning topics the interviewees would find, such as the division of tasks and personal life. One sealed envelop with both versions of the questionnaire (female and male versions) and free and informed consent forms was given to the participants. At this point, information concerning the study and instructions to complete the instrument were provided and a deadline was established.

A total of 250 questionnaires were distributed to 125 couples. The questionnaires were returned in 10 days on average. As was expected, some of the instruments were not returned and others presented errors during data checking. After refinement, a final sample of 120 participants remained with data from 60 working fathers and 60 working mothers of preschool children with varied ages and socioeconomic status.

Data analysis. The variables of interest in this study, obtained from the Questionnaire on family and professional lives, were analyzed using descriptive statistics, such as central tendency and dispersion. An analysis of internal consistency (Cronbach's alpha) of the scales selected was performed to verify the reliability of the measures in the context of this study (Cozby, 2003). For the coefficient of 
Cronbach's alpha to be considered appropriate, it has to be above 0.7 , though when scales have less than ten items, values above 0.5 are considered to be appropriate (Pallant, 2001). From this perspective, the Cronbach's alpha coefficients of the scales analyzed in this study are considered appropriate.

To verify potential correlations among the variables of interest, Pearson's correlation test was used. The parametric One-Way ANOVA test $(p<.001 ; p<.01$; and $p<0=.05)$ was used to verify differences between the groups. The statistical tests were performed using SPSS, version 16.0.

\section{Ethical Considerations}

The project was submitted to and approved by the Institutional Review Board of the Faculty of Philosophy, Sciences and Letters of Ribeirão Preto, University of São Paulo (Process no. 291/2006).

\section{Results}

The results are presented in two blocks of information: the first block presents the results obtained through Person's correlation tests for the scales of interest and the second presents data concerning the differences found between couples with one and two children.

Table 2 presents correlations between the scales.

Table 2

Person's Correlations Between the Scales Personal Well-being, Interactions Between Parents and Children and Behavior of Parents Toward Their Children

\begin{tabular}{lccc}
\hline Scales & 1 & 2 & 3 \\
\hline 1. Personal Well-being (Health problems) & - & ns & $-.368^{*}$ \\
$\begin{array}{l}\text { 2. Interactions between parents and children } \\
\text { 3. Parents' behavior toward children (parental }\end{array}$ & & - & $.416^{*}$ \\
practices) & & & - \\
\hline
\end{tabular}

Note. $\mathrm{ns}=$ no significant correlation.

$* p<.001$.

No significant correlation was found in regard to parents' health problems and interaction between parents and children. We verified, however, that in regard to childrearing practices and health problems, the more health problems reported by parents, the less appropriate childrearing practices they used $(r=-.368 ; p<.001)$. Additionally, a significant correlation was found between interactions and child-rearing practices, that is, the more positive interactions with children the parents reported the better and more positive the parental practices reported $(r=-.416 ; p<.001)$.

The computation of differences (One-Way ANOVA) between the scales Personal Well-being (health problems), Interactions between parents and children and Parental behavior toward children (parental practices) between families with one child and two children showed statistically significant differences in regard to the score for the variable "Behavior or parents toward to children (parental practices)"
$(F(111)=4.858, p<.05)$. These differences indicate that the parental practices reported by the participants vary according to the number of children. There were also statistically significant differences between parents with one child and parents with two children in regard to the score obtained for the variable "Interactions between parents and children" $(F(104)=4.266, p<.05)$. Therefore, in the same way that parental practices vary depending on the number of children, parental interactions also vary according to the quantity of children (one or two). No difference, however, was found between the groups in regard to well-being (health problems) as reported by the parents. Such a result suggests that the number of children does not influence aspects of personal well-being reported by parents.

\section{Discussion}

This study was based on the hypothesis that living conditions of parents influence their routine practices toward their children and that child-rearing practices may be related to the parents' health conditions, while these may be either risk factors or mechanisms of protection. A preliminary analysis of data of an exploratory nature confirms this hypothesis: the data revealed that the more health problems reported by the parents, the less appropriate the child-rearing practices they reported. Hence, parental health problems constitute a risk factor for child development. Such findings were in agreement with those of studies by Ferriolli, Marturano and Puntel (2007), Gomide et al. (2005), Menegatti (2002), Mendes, Loureiro, and Crippa (2008) and Zanfelici (2009) addressing stress and depression, which report there is a relationship between parents' well-being and parental practices.

Negative parental practices influence the level of parents' irritability, leading to the emergence or maintenance of aggressive behavior between children and parents, favoring counter-attack responses of parents in the face of aggressive behavior of children (Kazdin \& Whitley, 2003). In this way, a vicious cycle of negative exchange emerges affecting both parents and children. It is worth mentioning that populations such as the studied sample are more susceptible to stress due to the presence of small children in the family (Diniz, 1999).

According to Gravena (2006), mothers with less time for self-care may have less of a disposition to interact with children, as stress and tiredness can affect the characteristics of maternal positive exchanges such as creativity, patience and energy levels. Even though this study does not show significant differences in the co-relationship between interactions of parents with children and the parents' health problems, Gravena's assumptions can also be employed in this study's findings since parental health problems may affect their level of patience when dealing with their children's problems.

In regard to the relationship between parental practices and interactions between parents and children, the data indicate that the more positive interactions with children 
are reported to be by parents, the better and more positive the parental practices they report. The data seem to suggest that parents who establish more positive parental practices are those who report more interactions with children. These findings are in accordance with the study by Gomes, Crepaldi and Brigas (2013) and Zanfelici (2009). Zanfelici (2009) analyzed the relationships among stress, burnout, and the parental involvement of working mothers of preschool children attending a public day care and found that conflicts resulting from workload affecting the mothers' personal and professional lives were associated with reports of less frequent and less satisfactory interactions established between mothers and children. Our hypothesis in this study was that the inability of parents to appropriately deal with the problems presented by their children may be associated with the less frequent interactions they reported.

Additionally, the number of children seems to influence the family life of working parents of small children dealing with the challenge of reconciling demands from both family and professional lives, since the results suggest that the number of children influences parental practices and interactions between parents and children. These results are also reported by other studies (Dunn \& Kendrick, 1980), indicating an increased incidence of clashes, prohibitions, and maternal reprimands and reduced maternal initiatives for positive interactions after the arrival of a second child.

These results show a need to ensure that workers receive support to help them reconcile work and family, especially when children are small and families have more than one child. Among the interventions needed to promote appropriate child development is the expansion of support networks combined with a supply of day care for children, which, even though are an essential and effective support for families, seem to be found in insufficient number. As stressed by Zanfelici (2009), when mothers and fathers work outside of the home, part-time day care services do not meet the children's needs concerning care and education in their early years and the lack of this kind of services is a reality in all regions of Brazil. It also seems essential to improve the parents' level of information and their skills to access resources within the community in order to promote a more positive dynamic within the family and consequently improve their members' levels of well-being.

More specifically, according to Dessen and Polonia (2007), family education programs or public policies directed to health promotion should take into account factors such as stress, conflict resolution, and the reestablishment of a healthy family dynamics, as well as encourage the establishment of social support networks, whether within the community itself, within service centers, or in schools, since school plays a relevant role in contemporary societies. One recent case of intervention designed to promote appropriate family interactions that can be mentioned is the one developed by Pardo and Carvalho (2011), in which a group of mothers participated in eight meetings to discuss relationship difficulties experienced with their children, to learn principles regarding behavior control and about the phases of child development. The intervention resulted in more frequent dialogue with children, increased concern to dedicate more time to children and to understanding children's points of views, establishing limits, and involving other people in the family, consequently, promoting changes in the family microsystem dynamics.

Finally, the results indicate the influence of interactions within the family on child development processes. According to Pereira-Silva and Dessen (2001), the family is a group with especially varied relationship dynamics, the functioning of which can change due to any change that may occur in one of its members or in the group as a whole. Results show that, as stressed by Sapienza and Pedromônico (2005), risk factors are rarely isolated events because usually they are part of a complex environment, which when interconnected, are a mechanism that influences the individual. These assumptions are in accordance with the bioecological approach (Bronfenbrenner, 1979/1996) and favor a broader view of the identification of potential factors that may be related to child development.

\section{Final Considerations}

This study's objective was to contribute to the identification of potential relationships between certain aspects of the personal lives of mothers and fathers and interactions they establish with preschool children. Information acquired can contribute to the investigated universe, since the identification of what influences parental practices, considering that these are predictors of appropriate child development, opens up the possibility to develop and expand projects, material, and preventive practices that can be implemented in schools, communities, or even in situations observed in clinical practice. For instance, the development of intervention programs designed to promote the quality of the personal lives of working parents with preschool children, as well as interventions and informative material encouraging positive interactions between parents and children and the development of child-rearing practices, can be a way to prevent risks to child development.

It is, however, important to note that this study's results cannot be generalized, since the study was conducted in a single city of average size in the interior of the state of São Paulo with a sample that is not representative of the various social strata that compose Brazil, given the high educational level and income reported by the participants.

Carmo and Alvarenga (2012) compared the use of coercive practices of 40 mothers of children aged 5 to 6 years old of both sexes and half the participants had a low socioeconomic status, while the other half had an average/ high socioeconomic level. The results showed that mothers with low socioeconomic levels more frequently reported physical punishment while those with better socioeconomic 
status and higher education presented a greater repertoire of strategies to regulate child behavior.

The prevalence of data from a wealthier share of the population may be explained by the fact that potential participants took into account the length of the instrument. Considering that data were collected for a study developed within the doctoral program of the second author, within an inter-cultural project developed by a group of European researchers called Famwork and linked to the research group of the University of Porto, the use of this instrument enabled comparisons between aspects of the families and occupations of working parents with small children in Brazil and in European countries, such as presented by Fontaine and Matias (2008). In addition to this study, many other studies (Martinez, 2007; Martinez, Biasoli-Alves, \& Fontaine, 2007; Martinez et al., 2009; Souza \& Martinez, 2008) have been conducted, selecting and comparing different information addressed by the instrument.

Based on the previous discussion, future studies can re-formulate and optimize the questionnaire to be used in similar studies to minimize the time spent by the participants answering the instrument, enabling other populations with lower educational levels to complete it, who, due to the extensive and complex nature of the instrument may have not participated in the study. More specifically for this study, new research can complement and expand the validity of findings, enlarging the sample for various strata and characteristics of the population using specific instruments for each variable and analyzing data from a qualitative perspective.

\section{References}

Alvarenga, P., \& Piccinini, C. A. (2001). Práticas educativas maternas e problemas de comportamentos em préescolares. Psicologia: Reflexão e Crítica, 14(3), 449460. doi:10.1590/S0102-79722001000300002

Bolsoni-Silva, A. T., \& Marturano, E. M. (2002). Práticas educativas e problemas de comportamento: Uma análise à luz das habilidades sociais. Estudos de Psicologia (Natal), 7(2), 227-235. doi:10.1590/S1413-294X2002000200004

Bolsoni-Silva, A. T., \& Marturano, E. M. (2007). A qualidade da interação positiva e da consistência parental na sua relação com problemas de comportamentos de préescolares. Interamerican Journal of Psychology, 41(3), 349-358.

Bolsoni-Silva, A. T., \& Marturano, E. M. (2008). Habilidades sociais educativas parentais e problemas de comportamento: Comparando pais e mães de préescolares. Aletheia, (27), 126-138.

Bolsoni-Silva, A. T., \& Loureiro, S. R. (2011). Práticas educativas parentais e repertório comportamental infantil: Comparando crianças diferenciadas pelo comportamento. Paidéia (Ribeirão Preto), 21(48), 61-71. doi:10.1590/S0103-863X2011000100008
Bronfenbrenner, U. (1996). Ecologia do desenvolvimento humano: Experimentos naturais e planejados. Porto Alegre, RS: Artes Médicas. (Original publicado em 1979)

Bronfenbrenner, U., \& Ceci, S. J. (1994). Nature-nurture reconceptualized in developmental perspective: A bioecological model. Psychological Review, 101(4), 568586. doi:10.1037/0033-295X.101.4.568

Carmo, P. H. B., \& Alvarenga, P. (2012). Práticas educativas coercitivas de mães de diferentes níveis socioeconômicos. Estudos de Psicologia, 17(2), 191197. doi:10.1590/S1413-294X2012000200001

Cecconello, A. M., \& Koller, S. H. (2003). Inserção ecológica na comunidade: Uma proposta metodológica para o estudo de famílias em situação de risco. Psicologia: Reflexão e Crítica, 16(3), 515-524. doi:10.1590/S0102-79722003000300010

Coley, R. L. (2001). (In)visible men: Emerging research on low-income, unmarried, and minority fathers. American Psychologist, 56(9), 743-753. doi:10.1037/0003-066X.56.9.743

Coser, D. S. (2009). Avaliação de programa para capacitar pais como agentes de promoção de comportamentos de estudo (Unpublished master's thesis). Universidade Federal de São Carlos, São Carlos, SP.

Cozby, P. C. (2003). Métodos de pesquisa em ciências do comportamento. São Paulo, SP: Atlas.

Dessen, M. A., \& Polonia, A. C. (2007). A família e a escola como contextos de desenvolvimento humano. Paidéia (Ribeirão Preto), 17(36), 21-32. doi:10.1590/S0103-863X2007000100003

Diniz, G. R. S. (1999). Homens e mulheres frente à interação casamento-trabalho: Aspectos da realidade brasileira. In T. Férez-Carneiro (Org.), Casal e família: Entre a tradição e a transformação (pp. 31-54). Rio de Janeiro, RJ: NAU.

Dunn, J., \& Kendrick, C. (1980). The arrival of a sibling: Changes in patterns of interaction between mother and firsborn child. Journal of Child Psychology and Psychiatry, 21(2), 119-132. doi:10.1111/j.1469-7610.1980.tb00024.x

EU-Project. (2003). FamWork: Family life and professional work: Conflict and synergy. Questionário sobre a vida familiar e profissional. Versões masculina e feminina. Porto, Portugal: Universidade do Porto.

Ferreira, M. C. T., \& Marturano, E. M. (2002). Ambiente familiar e os problemas do comportamento apresentado por crianças com baixo desempenho escolar. Psicologia: Reflexão e Crítica, 15(1), 33-44. doi:10.1590/S0102-79722002000100005

Ferriolli, S. H. T., Marturano, E. M., \& Puntel, L. P. (2007). Contexto familiar e problemas de saúde mental infantil no Programa Saúde da Família. Revista de Saúde Pública, 41(2), 251-259. doi:10.1590/S0034-89102006005000017 
Fiorin, P. C., Patias, N. D., \& Dias, A. C. G. (2011). Reflexões sobre a mulher contemporânea e a educação dos filhos. Revista Sociais e Humanas, 24(2), 121-132. Retrieved from http://cascavel.ufsm.br/revistas/ojs2.2.2/index.php/sociaisehumanas

Fontaine, A. M. (2007). Relatório do projeto FamWork. Porto, Portugal: Universidade do Porto.

Fontaine, A. M., \& Matias, M. (2008). Family, work and parenting: International perspectives. Porto, Portugal: Livpsic/Legis.

Gomes, L. B., Crepaldi, M. A, \& Brigas, M. (2013). $\mathrm{O}$ engajamento paterno como fator de regulação da agressividade em pré-escolares. Paidéia (Ribeirão Preto), 23(54), 21-29. doi:10.1590/198243272354201304.

Gomide, P. I. C. (2006). IEP: Inventário de Estilos Parentais: Modelo teórico: Manual de aplicação, apuração e interpretação. Petrópolis, RJ: Vozes.

Gomide, P. I. C., Salvo, C. G., Pinheiro, D. P. N., \& Sabbag, G. M. (2005). Correlação entre práticas educativas, depressão, estresseehabilidades sociais. PsicoUSF, 10(2), 169-178. doi:10.1590/S1413-82712005000200008

Gravena, A. C. (2006). Retorno ao trabalho após o nascimento de um filho: Percepções de professoras sobre sua experiência. (Unpublished master's thesis). Universidade Federal de São Carlos, São Carlos, SP.

Kazdin, A. E., \& Whitley, M. K. (2003). Treatment of parental stress to enhance therapeutic change among children referred for aggressive and antisocial behavior. Journal of Consulting and Clinical Psychology, 71(3), 504-515. doi:10.1037/0022-006X.71.3.504

Marçal, V. P. B., \& Silva, S. M. C. (2006). A queixa escolar nos ambulatórios públicos de saúde mental: Práticas e concepções. Psicologia Escolar e Educacional, 10(1), 121-131. doi:10.1590/S1413-85572006000100011

Martinez, C. M. S. (1998). Da família à escola: Ingresso de crianças de 1 a 3 anos em novo contexto de socialização (Unpublished doctoral dissertation). Universidade Federal de São Carlos, São Carlos, SP.

Martinez, C.M. S. (2007). Conciliação entre responsabilidades do trabalho profissional e demandas da vida familiar: A situação de pais trabalhadores com filhos pequenos no interior do estado de São Paulo/Brasil: Relatório das atividades. São Paulo, SP: CNPq.

Martinez, C. M. S., Bilasoli-Alves, Z. M. M., \& Fontaine, A. M. (2007). Conciliação de demandas de trabalho profissional e vida familiar de pais trabalhadores com filhos pequenos no interior do Estado de São Paulo/ Brasil [Resumo]. Congresso Internacional de Educação Familiar, 11, 124-125.

Martinez, C. M. S., Pamplin, R. C. O., \& Fontaine, A. M. (2009). Percepção sobre as necessidades de filhos préescolares: Comparação entre mães e pais trabalhadores do Brasil. Psicologia, Educação e Cultura, 13(1), 73-90.
Masten, A. S. (2001). Ordinary magic: Resilience processes in development. American Psychologist, 56(3), 227-238. doi:10.1037/0003-066X.56.3.227

Masten, A. S., Best, K. M., \& Garmezy, N. (1990). Resilience and development: Contributions from de study of children who overcome adversity. Development and Psychology, 2(4), 425-444. doi:10.1017/S0954579400005812

Matias, M., Andrade, C., Fontaine, A. M., Alves, Z. B., \& Martinez, C. M. S. (2008). Gender differences in family to work facilitation in Portuguese and Brazilian families. In A. M. Fontaine \& M. Matias (Eds.), Family, work and parenting international perspectives (pp. 79-94). Porto, Portugal: Livpsic.

Mendes, A. V., Loureiro, S. R., \& Crippa, J. A. S. (2008). Depressão materna e a saúde mental de escolares. Revista de Psiquiatria Clínica, 35(5), 178-186. doi: 10.1590/S0101-60832008000500002

Menegatti, C. L. (2002). Filhos e depressão infantil: Uma abordagem comportamental (Unpublished master's thesis). Universidade Federal do Paraná, Curitiba, PR.

Pallant, J. (2001). SPSS - Survival manual. Philadelphia, PA: Open University Press.

Pereira-Silva, N. L., \& Dessen, M. A. (2001). Deficiência mental e família: Implicações para o desenvolvimento da criança. Psicologia: Teoria e Pesquisa, 17(2), 133-141. doi:10.1590/S0102-37722001000200005

Pardo, M. B. L., \& Carvalho, M. M. S. B. (2011). Grupo de orientação de mães no contexto de uma clínicaescola. Paidéia (Ribeirão Preto), 21(48), 93-100. doi:10.1590/S0103-863X2011000100011

Perlin, G., \& Diniz, G. (2005). Casais que trabalham são felizes: Mito ou realidade? Psicologia Clínica, 17(2), 15-29. doi:10.1590/S0103-56652005000200002

Pianta, R. C., \& Walsh, D. J. (1996). High-risk children in the schools: Creating sustaining relationships. New York, NY: Routledge.

Piccinini, C. A., Pereira, C. R. R., Marin, A. H., Lopes, R. C. S., \& Tudge, J. (2007). O nascimento do segundo filho e as relações familiares. Psicologia: Teoria e Pesquisa, 23(3), 253-261. doi:10.1590/S0102-37722007000300003

Salvo, C. G., Silvares, E. F. M., \& Toni, P. M. (2005). Práticas educativas como forma de predição de problemas de comportamento e competência social. Estudos de Psicologia, 22(2), 185-195. doi:10.1590/S0103-166X2005000200008

Santos, L. C., \& Marturano, E. M. (1999). Crianças com dificuldade de aprendizagem: Um estudo de seguimento. Psicologia: Reflexão e Crítica, 12(2), 377-394. doi:10.1590/S0102-79721999000200009

Sapienza, G., \& Pedromônico, M. R. M. (2005). Risco, proteção e resiliência no desenvolvimento da criança e do adolescente. Psicologia em Estudo, 10(2), 209-216. doi:10.1590/S1413-73722005000200007 
Souza, C. P., \& Martinez, C. M. S. (2008). Práticas educativas de pais e mães trabalhadores com filhos em idade pré-escolar no início do século XXI: Subsídios para elaboração de estratégias de intervenção no cotidiano familiar (Unpublished manuscript). Universidade Federal de São Carlos, São Carlos, SP.

Wagner, A., Predebon, J., Mosmann, C., \& Verza, F. (2005). Compartilhar tarefas? Papéis e funções de pai e mãe na família contemporânea. Psicologia: Teoria e Pesquisa, 21(2), 181-186. doi:10.1590/S0102-37722005000200008

Weber, L. N. D., Prado, P. M., Viezzer, A. P., \& Brandenburg, O. J. (2004). Identificação de estilos parentais: O ponto de vista dos pais e dos filhos. Psicologia: Reflexão e Crítica, 17(3),323-331. doi:10.1590/S0102-79722004000300005

Williams, L. C. A., \& Aiello, A. L. R. (2004). Empoderamento de famílias: O que vem a ser e como medir? In E. G. Mendes, M. A. Almeida, \& L. C. A. Williams (Orgs.), Temas em educação especial: Avanços recentes (pp. 197202). São Carlos, SP: EDUFSCar.

Yunes, M. A. M., \& Szymanski, H. (2001). Resiliência: Noções, conceitos afins e considerações críticas. In J. P. Tavares (Org.), Resiliência e educação (pp. 13-42). São Paulo, SP: Cortez.

Zanfelici, T. O. (2009). Fatores de risco ao envolvimento materno com filhos pré-escolares: Associações com estresse e burnout (Unpublished master's thesis). Universidade Federal de São Carlos, São Carlos, SP.

Danila Secolim Coser is a Ph.D. in Special Education from Universidade Federal de São Carlos.

Cláudia Maria Simões Martinez is a Professor of the Centro de Ciências Biológicas e da Saúde, Universidade Federal de São Carlos.

Renata Christian de Oliveira Pamplin is a Ph.D. in Special Education from Universidade Federal de São Carlos.

Received: Mar. $26^{\text {th }} 2010$

$1^{\text {st }}$ Revision: Oct. $19^{\text {th }} 2011$

Approved: Feb. 24 2012

How to cite this article:

Coser, D. S., Martinez, C. M. S., \& Pamplin, R. C. O. (2013). Personal well-being and family interactions of working couples with preschool children: A correlational study. Paidéia (Ribeirão Preto), 23(56), 339-347. doi: 10.1590/1982-43272356201308 


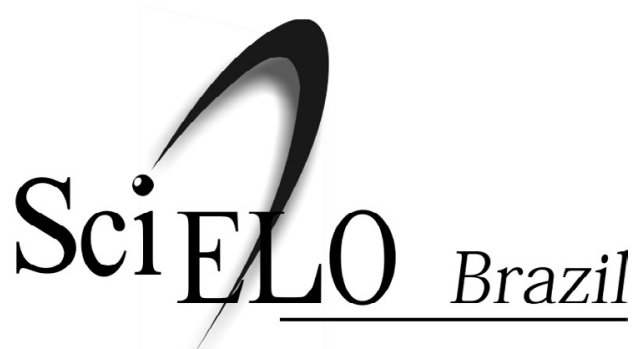

The SciELO interface provides easy access to the tables of content and to the full-text articles.

The SciELO interface also provides the retrieval of articles by the author's name, the words from title, abstract and descriptors, in addition to providing bibliometric indicators and consultation indicators.

The articles are enriched with connections to the LILACS, MEDLINE and PubMed databases.

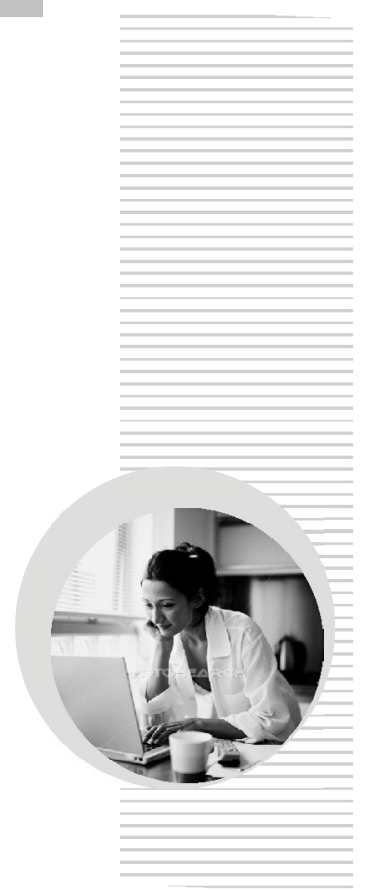

Paidéia (Ribeirão Preto) is a part of SciELO Brazil:

\section{www.scielo.br/paideia}

The SciELO interface provides access to a network of SciELO websites, gathering the major scientific journals of Latin America, Caribbean, Spain, Portugal and South Africa:

\section{www.scielo.org}

The electronic library is a project developed by the São Paulo Research Fundation (FAPESP), in partnership with the Latin American and Caribbean Center on Health Sciences Information (BIREME) and the National Council for Scientific and Technological Development (CNPq). 